\title{
Determination of Heavy Metals in Selected Fish Species found in Kwalkwalawa River, Dundaye. Sokoto State
}

\author{
Ejike, L. O. and Liman, M. G. \\ Department of Pure and Applied Chemistry, Usmanu Danfodiyo University, Sokoto. P.M.B. 2346, Sokoto State, \\ Nigeria
}

\begin{abstract}
This work reports the concentrations of heavy metals ( $\mathrm{Zn}, \mathrm{Cu}, \mathrm{Pb}, \mathrm{Cd}, \mathrm{Fe}$ and $\mathrm{Ni}$ ) in the head, muscle and tail of two species of fish; Clarias gariepinus (catfish) and Oreochromis niloticus (Tilapia fish) obtained from Kwalkwalawa River along Dundaye village, Sokoto State. The analysis was done using Atomic Absorption Spectroscopy (AAS). The results of this analysis reported that there were high level of the analyzed metals (Zn; $71.60 \mathrm{mg} / \mathrm{kg}, \mathrm{Cu} ; 21.10 \mathrm{mg} / \mathrm{kg}, \mathrm{Pb} ; 24.10 \mathrm{mg} / \mathrm{kg}, \mathrm{Cd} ; 1.50 \mathrm{mg} / \mathrm{kg}, \mathrm{Fe} ; 46.60 \mathrm{mg} / \mathrm{kg}$ and $\mathrm{Ni} ; 2.60$ $\mathrm{mg} / \mathrm{kg}$ ) in Clarias gariepinus and (Zn; $58.80 \mathrm{mg} / \mathrm{kg}, \mathrm{Pb} ; 16.40 \mathrm{mg} / \mathrm{kg}, \mathrm{Cu} ; 17.40 \mathrm{mg} / \mathrm{kg}, \mathrm{Fe} ; 39.60 \mathrm{mg} / \mathrm{kg}, \mathrm{Cd}$; $1.30 \mathrm{mg} / \mathrm{kg}$ and $\mathrm{Ni} ; 1.50 \mathrm{mg} / \mathrm{kg}$ ) in Oreochromis niloticus sample compared to the World Health Organization (WHO) standard. Hence, the fish obtained from this river may therefore be not safe for consumption.

Keywords: Clarias gariepinus, Oreochromis niloticus, Kwalkwalawa River, Heavy metals.
\end{abstract}

\section{Introduction}

Heavy metal is any metallic chemical element that has a relatively high density and is toxic or poisonous at low concentrations (Lenntech, 2004). Examples of heavy metals include mercury, cadmium, arsenic, copper, chromium, thallium and lead. As trace elements, some heavy metals (e.g. copper, iron, zinc, manganese, cobalt and selenium) are essential to maintain the metabolism of the human body. However, at higher concentrations they can lead to poisoning (Olade, 1987).

Heavy metals are important group of chemical elements, whereby food is the main route for entry into human body tissues (Olowu et al., 2010). Some heavy metals irreversibly are bound to human body tissues, e.g., cadmium to kidneys and lead to bones (Kaplan et al., 2011).

In recent years, there have been keen concerns about the contamination of aquatic environment and the attendant consequences on human health (Kelle et al., 2015). The high rise in civilization and the progress of industries have led to increased emission of pollutants into the ecosystems. Some of these pollutants, which include heavy metals, are directly discharged by industrial plants and municipal sewage treatment plants; others come from polluted runoff in urban and agricultural areas (Abida et al., 2009).

Many dangerous chemical elements such as heavy metals, if released into aquatic environment, accumulate in the soil and sediments of water bodies. The lower aquatic organisms absorb and transfer them through the food chain to higher trophic levels, including fish (Kelle et al., 2015).

Fish is one of the most widely distributed organisms in the aquatic environment and considered as one of the main protein source of food for human (Rashed, 2001). Among water foods, fish are commonly consumed and hence, are a connecting link for the transfer of toxic heavy metals in human beings (Olowu et al., 2012). Heavy metals have the tendency to accumulate in various organs of fish which in turn may enter into human metabolism through consumption causing serious health hazards (Khalifa et al., 2010).

Fish has been recognized as an important food source for the human body. Fish provides essential fatty acids like Omega 3, proteins, vitamins, and minerals (Enkeleda et al., 2013). However, despite its nutritional value, consumption of fish contaminated with heavy metals brings hazard concern for the human consumers. It has been reported that prolonged consumption of unsafe concentrations of heavy metals through foodstuff may lead to the chronic accumulations of the metals in the kidney and liver of humans causing disruption of numerous biochemical processes, leading to cardiovascular, nervous, kidney and bone diseases as heavy metals bioaccumulate (Jarup, 2003).

The rate of bioaccumulation of heavy metals in aquatic organisms depends on the ability of the organisms to digest the metals and the concentration of such metal in the water body. Also, it has to do with the concentration of the heavy metal in the surrounding soil sediments as well as the feeding habits of the organism (Eneji et al., 2011).

There is increasing concern about the quality of aquatic food (e.g. fish) in several parts of the world. The determination of toxic elements in food has prompted studies on toxicological effects of heavy metals in foods (Indrajit et al., 2011). 


\section{Reagents and instruments}

\section{Materials And Methods}

All reagents $\left(\mathrm{HNO}_{3}\right.$ and $\left.\mathrm{HCl}\right)$ used were of British drug house $(\mathrm{BDH})$ grades. Glass wares; beaker, measuring cylinder and volumetric flask used were washed and rinsed with deionized water before using.

\section{Sample collection}

The fish samples were collected from Kwalkwalawa River which passes through Usmanu Danfodiyo university, Sokoto. The fish samples considered are; Clarias gariepinus (Catfish) and Oreochromis niloticus (Tilapia fish). The samples were bought at the river bank after the villagers had caught them using fishing net. After collection, the fish samples were transported to the Usmanu Danfodiyo University's Chemistry laboratory for further analysis.

\section{Methods}

Preparation of aqua regia solution

Aqua regia solution, $\mathrm{HNO}_{3}-\mathrm{HCl}$ (3:1) was prepared by adding $25 \mathrm{ml}$ of Conc. $\mathrm{HCl}$ to $75 \mathrm{ml}$ of Conc. $\mathrm{HNO}_{3}$.

\section{Preparation/digestion of fish sample}

The fish samples were prepared using the method used by Ozmen et al, (2004), the part of fish sample such as heart, muscle and tail needed for the analysis were separated and oven-dried at $80^{\circ} \mathrm{C}$ for $48 \mathrm{hrs}$. These samples were ground to powder using clean mortar and pestle. One (1) gram of each homogenized fish part was weighed into different beakers and into each beaker was added $20 \mathrm{ml}$ of the mixture of aqua regia solution and digested to a clear colorless solution using hot plate at $80^{\circ} \mathrm{C}$. The digests were allowed to cool, filtered through Whatmann No.1 filter paper and then transferred to different $50 \mathrm{ml}$ volumetric flasks and filled to $25 \mathrm{ml}$ mark with de-ionized water and kept ready for AAS analysis. All the digested samples were taken to Energy Research Centre, Usmanu Danfodiyo University, Sokoto for AAS analysis.

\section{Results}

\section{Results And Discussion}

The results gotten from the atomic absorption spectroscopy (AAS) analysis of the various prepared samples are given in the table below;

Table 1: Concentration of heavy metals in fish part in $(\mathrm{mg} / \mathrm{kg})$

\begin{tabular}{|l|l|l|l|l|l|l|l|}
\hline S/No & $\begin{array}{l}\text { SAMPLE } \\
\text { CODE }\end{array}$ & ZINC $(\mathrm{Zn})$ & LEAD $(\mathrm{Pb})$ & COPPER $(\mathrm{Cu})$ & IRON (Fe) & $\begin{array}{l}\text { CADMIUM } \\
(\mathrm{Cd})\end{array}$ & $\begin{array}{l}\text { NICKEL } \\
(\mathrm{Ni})\end{array}$ \\
\hline 1 & $\mathrm{~A}$ & 85.10 & 25.40 & 31.90 & 76.60 & 2.10 & 4.50 \\
\hline 2 & $\mathrm{~B}$ & 65.80 & 18.90 & 17.10 & 32.50 & 1.00 & 1.70 \\
\hline 3 & $\mathrm{C}$ & 63.40 & 17.90 & 15.20 & 30.80 & 1.10 & 1.50 \\
\hline 4 & $\mathrm{D}$ & 74.40 & 20.90 & 25.70 & 5440 & 1.60 & 2.40 \\
\hline 5 & $\mathrm{E}$ & 44.20 & 10.80 & 10.80 & 14.70 & 1.30 & $1 . .40$ \\
\hline 6 & $\mathrm{~F}$ & 57.90 & 19.60 & 14.80 & 29.80 & 1.20 & 0.80 \\
\hline
\end{tabular}

Key

$\mathrm{A}=$ The head part of Clarias gariepinus (Catfish)

$\mathrm{B}=$ The body of Clarias gariepinus (Catfish)

$\mathrm{C}=$ The tail part of Clarias gariepinus (Catfish)

$\mathrm{D}=$ The head part of Oreochromis niloticus (Tilapia fish)

$\mathrm{E}=$ The body (muscle) part of Oreochromis niloticus (Tilapia fish)

$\mathrm{F}=$ The tail part of Oreochromis niloticus (Tilapia fish)

Table 2: World Health Organization (WHO) recommended heavy metal levels in fish in (mg/kg)

\begin{tabular}{|l|l|l|l|l|l|l|}
\hline $\mathrm{Zn}$ & $\mathrm{Pb}$ & $\mathrm{Cu}$ & $\mathrm{Fe}$ & $\mathrm{Cd}$ & $\mathrm{Ni}$ & Reference \\
\hline 5.000 & 0.010 & 2.250 & 0.300 & 0.010 & 0.100 & WHO 2003 \\
\hline
\end{tabular}

Table 3: Average concentration of heavy metals in each of the fish sample in $(\mathrm{mg} / \mathrm{kg})$

\begin{tabular}{|l|l|l|l|l|l|l|}
\hline FISH SPECIES & ZINC $(\mathrm{Zn})$ & LEAD $(\mathrm{Pb})$ & COPPER $(\mathrm{Cu})$ & IRON $(\mathrm{Fe})$ & CADMIUM (Cd) & NICKEL (Ni) \\
\hline $\begin{array}{l}\text { Clarias gariepinus } \\
\text { (Catfish) }\end{array}$ & 71.60 & 21.40 & 21.10 & 46.60 & 1.50 & 2.60 \\
\hline $\begin{array}{l}\text { Oreochromis niloticus } \\
\text { (Tilapia fish) }\end{array}$ & 58.80 & 16.40 & 17.40 & 39.60 & 1.30 & 1.50 \\
\hline
\end{tabular}




\section{Discussion}

The results obtained from the Atomic Absorption Spectroscopy (AAS) analysis have shown that these heavy metals; $\mathrm{Zn}, \mathrm{Pb}, \mathrm{Cu}, \mathrm{Fe}, \mathrm{Cd}$, and $\mathrm{Ni}$ were all present in all the two fish samples analyzed as shown in table 1. The permissible limit of the concentrations of $\mathrm{Zn}, \mathrm{Pb}, \mathrm{Cu}, \mathrm{Fe}, \mathrm{Cd}$, and $\mathrm{Ni}$ in fishes according to World Health Organization (WHO) 2003 is presented in table 2.

From Table 1, it could be seen that sample A (head part of Catfish) and D (the head part of Tilapia fish) showed concentration of heavy metals that were more than the rest of the samples. This was not unexpected because past works on similar research had shown that the heavy metals tend to accumulate more in the head parts than the body (muscle) and the tail part of fishes (Khalifa et al., 2010). For samples B (muscle part of catfish) and $\mathrm{E}$ (muscle part of tilapia fish), aside from Cadmium which recorded concentration that is higher in $\mathrm{E}$ than in $\mathrm{B}(\mathrm{Cd} ; 1.30 \mathrm{mg} / \mathrm{kg}$ in $\mathrm{E}$, and $1.00 \mathrm{mg} / \mathrm{kg}$ in $\mathrm{B})$, the concentration of the other analyzed metals were higher in B than in E. For instance, Zn, Pb, Cu, Fe and Ni had concentration of $65.80 \mathrm{mg} / \mathrm{kg}, 18.90 \mathrm{mg} / \mathrm{kg}, 17.10$ $\mathrm{mg} / \mathrm{kg}, 32.50 \mathrm{mg} / \mathrm{kg}$ and $1.70 \mathrm{mg} / \mathrm{kg}$ respectively in sample B while their respective concentrations were 44.20 $\mathrm{mg} / \mathrm{kg}, 10.80 \mathrm{mg} / \mathrm{kg}, 10.80 \mathrm{mg} / \mathrm{kg}, 14.70 \mathrm{mg} / \mathrm{kg}$ and $1.40 \mathrm{mg} / \mathrm{kg}$ in Sample E. Also for sample C (tail part of catfish) and $\mathrm{F}$ (tail part of tilapia fish), aside from $\mathrm{Pb}$ and $\mathrm{Cd}$ which recorded concentration that were higher in $\mathrm{F}$ than in $\mathrm{C}$ (for $\mathrm{Pb} ; 19.60 \mathrm{mg} / \mathrm{kg}$ in $\mathrm{F}$ and $17.90 \mathrm{mg} / \mathrm{kg}$ in $\mathrm{C}$ while for $\mathrm{Cd} ; 1.20 \mathrm{mg} / \mathrm{kg}$ in $\mathrm{F}$ and $1.10 \mathrm{mg} / \mathrm{kg}$ in $\mathrm{C}$ ), the concentration of the other analyzed metals were higher in $\mathrm{C}$ than in $\mathrm{F}$. For instance, $\mathrm{Zn}, \mathrm{Cu}, \mathrm{Fe}$ and $\mathrm{Ni}$ had concentration of $63.90 \mathrm{mg} / \mathrm{kg}, 14.20 \mathrm{mg} / \mathrm{kg}, 30.80 \mathrm{mg} / \mathrm{kg}$ and $1.50 \mathrm{mg} / \mathrm{kg}$ in sample C respectively while their respective concentration were $57.90 \mathrm{mg} / \mathrm{kg}, 15.80 \mathrm{mg} / \mathrm{kg}, 49.80 \mathrm{mg} / \mathrm{kg}$ and $0.80 \mathrm{mg} / \mathrm{kg}$ in sample F. This was as a result of the scales found on the body of Oreochromis niloticus (Sample E) which was removed before the sample was treated prior to analysis. These scales were absent in Clarias gariepinus (Sample B). The scales have been found to help in the reduction of heavy metals accumulations on the fish body (Khalifa et al., 2010). Below are a detailed discussion on the concentrations of the various metals studied, the comparison of their concentrations with (i) similar studies (ii) international organizations standards and also, the implications of these results and their health consequences on human.

\section{Zinc}

Zinc had the highest concentration of all the heavy metals analyzed in sample A $(85.10 \mathrm{mg} / \mathrm{kg})$ while the lowest concentration of $\mathrm{Zn}$ was recorded in sample $\mathrm{E}(44.20 \mathrm{mg} / \mathrm{kg})$. The concentration of $\mathrm{Zn}$ in samples B, C, D and F were $65.80 \mathrm{mg} / \mathrm{kg}, 63.90 \mathrm{mg} / \mathrm{kg}, 74.40 \mathrm{mg} / \mathrm{kg}$ and $57.90 \mathrm{mg} / \mathrm{kg}$ respectively. The levels of $\mathrm{Zn}$ in samples A and D (the head parts of both fish samples; $85.10 \mathrm{mg} / \mathrm{kg}$ and $74.40 \mathrm{mg} / \mathrm{kg}$ respectively) were higher than the values; $7.68 \mathrm{mg} / \mathrm{kg}$ and $6.50 \mathrm{mg} / \mathrm{kg}$ gotten by Indrajit et al., (2011) in their study of heavy metals level in fish samples taken from river Yamuna (Delhi) in India. The levels of $\mathrm{Zn}$ in the body parts of both Oreochromis niloticus (sample B; $65.80 \mathrm{mg} / \mathrm{kg}$ ) and Clarias gariepinus (sample E; $44.20 \mathrm{mg} / \mathrm{kg}$ ) were higher than the results; $5.80 \mathrm{mg} / \mathrm{kg}$ and $6.49 \mathrm{mg} / \mathrm{kg}$ obtained by these scholars. Also, Zn had the concentration of 63.40 $\mathrm{mg} / \mathrm{kg}$ and $57.90 \mathrm{mg} / \mathrm{kg}$ in sample C and F (the tail parts of both Oreochromis niloticus and Clarias gariepinus) respectively which are higher than the ones $(6.68 \mathrm{mg} / \mathrm{kg}$ and $4.91 \mathrm{mg} / \mathrm{kg}$ ) reported by Indrajit et al., (2011). Table 3 showed the average heavy metals contents of each of the fishes used in this research; Oreochromis niloticus had an average $\mathrm{Zn}$ concentration of $58.80 \mathrm{mg} / \mathrm{kg}$, and $71.60 \mathrm{mg} / \mathrm{kg}$ for Clarias gariepinus which were higher than the values obtained by Indrajit et al.,(2011), $(6.38 \mathrm{mg} / \mathrm{kg}$ and $6.36 \mathrm{mg} / \mathrm{kg})$. And also, higher than the permissible limit reported by WHO 2003.

\section{Lead}

The head part of Clarias gariepinus (sample A) recorded the highest $\mathrm{Pb}$ concentration $(25.40 \mathrm{mg} / \mathrm{kg}$ ) of all the samples analyzed while the lowest $(10.80 \mathrm{mg} / \mathrm{kg}$ ) was recorded in sample E (muscl part of Oreochromis niloticu). $18.90 \mathrm{mg} / \mathrm{kg}, 17.90 \mathrm{mg} / \mathrm{kg}, 20.90 \mathrm{mg} / \mathrm{kg}$ and $19.60 \mathrm{mg} / \mathrm{kg}$ were the concentrations gotten from samples B, C, D and F respectively. The head parts of the fish samples (samples A and D) gave $\mathrm{Pb}$ concentrations; $25.40 \mathrm{mg} / \mathrm{kg}$ and $20.90 \mathrm{mg} / \mathrm{kg}$ respectively that were higher than the values; $0.75 \mathrm{mg} / \mathrm{kg}$ and $0.47 \mathrm{mg} / \mathrm{kg}$ obtained by Indrajit et al., (2011). Also, the muscle part concentration of $\mathrm{Pb}$ of $2.40 \mathrm{mg} / \mathrm{kg}$ for Clarias gariepinus and $0.22 \mathrm{mg} / \mathrm{kg}$ for Oreochromis niloticus gotten by Indrajit et al., (2011) was lower than the ones obtained in this study for Clarias gariepinus (samples B) and Oreochromis niloticus (sample E). For the average $\mathrm{Pb}$ concentration obtained in both Clarias gariepinus $(21.40 \mathrm{mg} / \mathrm{kg}$ ) and Oreochromis niloticus (16.40 $\mathrm{mg} / \mathrm{kg}$ ) were higher than the acceptable limit of $0.010 \mathrm{mg} / \mathrm{kg}$ according to WHO 2003

\section{Copper}

Sample E (tail part of Orechromis niloticus) showed the lowest $\mathrm{Cu}$ concentration with $10.80 \mathrm{mg} / \mathrm{kg}$ while the heat part of Clarias gariepinus (sample A) had the highest $\mathrm{Cu}$ concentration $(31.90 \mathrm{mg} / \mathrm{kg}) . \mathrm{The} \mathrm{Cu}$ concentration in sample B, C, D, and F were $17.10 \mathrm{mg} / \mathrm{kg}, 14.20 \mathrm{mg} / \mathrm{kg}, 25.70 \mathrm{mg} / \mathrm{kg}$ and $15.80 \mathrm{mg} / \mathrm{kg}$ respectively. Compared to Indrajit et al., (2011) results, the head parts of the fish samples (samples A and D) 
contained more $\mathrm{Cu}$ content than the $1.69 \mathrm{mg} / \mathrm{kg}$ and $1.50 \mathrm{mg} / \mathrm{kg}$ gotten by Indrajit and his mates. On the other hand, the body parts of both Clarias gariepinus (sample B; $17.10 \mathrm{mg} / \mathrm{kg}$ ) and Orechromis niloticus (sample E; $10.80 \mathrm{mg} / \mathrm{kg}$ ) had concentration higher than the values $(3.68 \mathrm{mg} / \mathrm{kg}$ and $1.39 \mathrm{mg} / \mathrm{kg}$ ) of Indrajit et al., (2011). Also, the tail parts of both catfish (sample C) and tilapia fish (sample F) showed concentrations that were higher than the values; $2.86 \mathrm{mg} / \mathrm{kg}$ and $1.43 \mathrm{mg} / \mathrm{kg}$ recorded by Indrajit et al., (2011). The average Cu contents in Clarias gariepinu (Catfish); $(21.10 \mathrm{mg} / \mathrm{kg})$ and in Tilapia fish $(17.40 \mathrm{mg} / \mathrm{kg})$ were higher than the value $(7.30$ $\mathrm{mg} / \mathrm{kg}$ ) obtained in Odumuyiwa's study. The $2.25 \mathrm{mg} / \mathrm{kg}$ of $\mathrm{Cu}$ concentration recommended by WHO is well below all the concentrations showed by all the samples.

\section{Cadmium}

The $\mathrm{Cd}$ concentrations are generally low in all the samples. The head parts of Clarias gariepiuns (sample A) led the rank with $2.10 \mathrm{mg} / \mathrm{kg}$ of Cd content while the body parts of the same fish sample (sample B) had the lowest $\mathrm{Cd}$ content with $1.00 \mathrm{mg} / \mathrm{kg}$. samples C, D, E and F had concentrations of $1.10 \mathrm{mg} / \mathrm{kg}, 1.60$ $\mathrm{mg} / \mathrm{kg}, 1.30 \mathrm{mg} / \mathrm{kg}$ and $1.20 \mathrm{mg} / \mathrm{kg}$ respectively. Comparison with the work of Indrajit et al., (2011) showed that the head parts of the fish samples (samples A and D) had concentrations lower than $6.10 \mathrm{mg} / \mathrm{kg}$ and 13.30 $\mathrm{mg} / \mathrm{kg}$ obtained by Indrajit et al., (2011). The muscle part of both Clarias gariepinus (sample B; $1.00 \mathrm{mg} / \mathrm{kg}$ ) and Oreochromis niloticus (sample E; $1.30 \mathrm{mg} / \mathrm{kg}$ ) gave the concentration of Cd lower than $4.57 \mathrm{mg} / \mathrm{kg}$ and $3.00 \mathrm{mg} / \mathrm{kg}$ values obtained by these scholars. Also, the tail part of Clarias gariepinus (sample C; $1.10 \mathrm{mg} / \mathrm{kg}$ ) and that of Oreochromis niloticus (sample F; $1.20 \mathrm{mg} / \mathrm{kg}$ ) gave Cd concentrations higher than; $0.03 \mathrm{mg} / \mathrm{kg}$ and $0.02 \mathrm{mg} / \mathrm{kg}$ reported by Indrajit et al (2011). The average concentrations of Cd in both catfish $(1.50 \mathrm{mg} / \mathrm{kg}) \mathrm{and}$ tilapia fish $(1.30 \mathrm{mg} / \mathrm{kg})$ in table 3 were found to be higher than the $0.026 \mathrm{mg} / \mathrm{kg}$ and $0.03 \mathrm{mg} / \mathrm{kg}$ recorded during Indrajit et al., (2011) research. And also, higher than the WHO recommended value of $0.010 \mathrm{mg} / \mathrm{kg}$.

\section{Iron}

Fe had its lowest concentration in sample $\mathrm{E}(14.70 \mathrm{mg} / \mathrm{kg})$ while sample A recorded the highest concentration of Fe with $(76.60 \mathrm{mg} / \mathrm{kg})$. The Fe concentration in sample B, C, D and F were $32.50 \mathrm{mg} / \mathrm{kg}, 30.8$ $\mathrm{mg} / \mathrm{kg}, 54.40 \mathrm{mg} / \mathrm{kg}$ and $29.80 \mathrm{mg} / \mathrm{kg}$ respectively. The concentration of sample A and D (the head parts of catfish and tilapia) were higher than the values; $20.00 \mathrm{mg} / \mathrm{kg}$ and $54.02 \mathrm{mg} / \mathrm{kg}$ gotten during Eneji et al., (2011) study of bioaccumulation of heavy metals in fish (Tilapia Zilli and Clarias gariepinus) from River Benue, Nigeria. However, body part of both Clarias gariepinus (sample B; $32.50 \mathrm{mg} / \mathrm{kg}$ ) and Oreochromis niloticus (sample E; $14.70 \mathrm{mg} / \mathrm{kg}$ ) had concentrations lower than the values $(41.3 \mathrm{mg} / \mathrm{kg}$ and $35.2 \mathrm{mg} / \mathrm{kg}$ ) of Eneji et al., (2011). The average concentrations of $\mathrm{Fe}$ in both Clarias gariepinus $(46.60 \mathrm{mg} / \mathrm{kg})$ and Oreochromis niloticus $(39.60 \mathrm{mg} / \mathrm{kg}$ ) in table 3 were found to be higher than the $0.20 \mathrm{mg} / \mathrm{kg}$ and $0.40 \mathrm{mg} / \mathrm{kg}$ recorded during Adewumi et al., (2014) research. And also, higher than $0.30 \mathrm{mg} / \mathrm{kg}$ recommended by WHO 2003.

\section{Nickel}

The head part of Clarias gariepinus (Sample A) showed the highest concentration of Ni (4.50 mg/kg) while sample F (tail part of Oreochromis niloticus) with $0.80 \mathrm{mg} / \mathrm{kg}$ recorded the least concentration of Ni. Samples B, C, D and E were $1.70 \mathrm{mg} / \mathrm{kg}, 1.50 \mathrm{mg} / \mathrm{kg}, 2.40 \mathrm{mg} / \mathrm{kg}$ and $1.40 \mathrm{mg} / \mathrm{kg}$ rich in Ni respectively. Sample A (the head pat of Catfish) had the same concentration as $4.50 \mathrm{mg} / \mathrm{kg}$ gotten during Indrajit et al., (2011) study for the head parts while sample D (the head of Tilapia fish) recorded value $(2.40 \mathrm{mg} / \mathrm{kg}) \mathrm{higher}$ than that of Indrajit et al.,(2011), (0.50 mg/kg). For the body Clarias gariepinus (sample B; $1.70 \mathrm{mg} / \mathrm{kg}$ ) and Oreochromis niloticus (sample E; $1.40 \mathrm{mg} / \mathrm{kg}$ ), the level of Ni obtained were higher than the ones $(0.04 \mathrm{mg} / \mathrm{kg}$ and $0.30 \mathrm{mg} / \mathrm{kg}$ ) obtained by same Indrajit et al., (2011). Also, the tail part of Clarias gariepinus (sample C) and Oreochromis niloticus (sample F) gave concentrations; $1.50 \mathrm{mg} / \mathrm{kg}$ and $0.80 \mathrm{mg} / \mathrm{kg}$ higher than $0.29 \mathrm{mg} / \mathrm{kg}$ and $0.30 \mathrm{mg} / \mathrm{kg}$ recorded by Indrajit et al., (2011). Table 3 showed average concentrations of Ni in Clarias gariepinus to be $2.60 \mathrm{mg} / \mathrm{kg}$ and and that of Oreochromis niloticus to be $1.50 \mathrm{mg} / \mathrm{kg}$. These were higher than the $1.28 \mathrm{mg} / \mathrm{kg}$ and $1.40 \mathrm{mg} / \mathrm{kg}$ recorded by Adewumi et al., (2014). And also higher than $0.10 \mathrm{mg} / \mathrm{kg}$ recommended by WHO 2003.

\section{Conclusion}

\section{Conclusion And Recommendations}

From the result obtained, it was seen that the heavy metals concentrations were all together high in the two fish samples analyzed. This study revealed that the concentration of these metals $(\mathrm{Zn} ; 71.60 \mathrm{mg} / \mathrm{kg}, \mathrm{Pb}$; $21.40 \mathrm{mg} / \mathrm{kg}, \mathrm{Fe} ; 46.60 \mathrm{mg} / \mathrm{kg}, \mathrm{Cd} ; 1.50 \mathrm{mg} / \mathrm{kg}$ and Ni; $2.60 \mathrm{mg} / \mathrm{kg})$ in Clarias gariepinus and (Zn; 58.80 $\mathrm{mg} / \mathrm{kg}, \mathrm{Pb} ; 164 \mathrm{mg} / \mathrm{kg}, \mathrm{Fe} ; 39.6 \mathrm{mg} / \mathrm{kg}, \mathrm{Cd} ; 1.30 \mathrm{mg} / \mathrm{kg}$ and $\mathrm{Ni} ; 1.50 \mathrm{mg} / \mathrm{kg}$ ) in Oreochromis niloticus were higher than the permissible limit ( $\mathrm{Zn} ; 5.000 \mathrm{mg} / \mathrm{kg}, \mathrm{Pb} ; 0.010 \mathrm{mg} / \mathrm{kg}, \mathrm{Cu} ; 2.250 \mathrm{mg} / \mathrm{kg}, \mathrm{Fe} ; 0.300 \mathrm{mg} / \mathrm{kg}, \mathrm{Cd}$; $0.010 \mathrm{mg} / \mathrm{kg}$ and $\mathrm{Ni} ; 0100 \mathrm{mg} / \mathrm{kg}$ ) stipulated by WHO 2003 . 
The fishes obtained from the river may be unsafe and dangerous for consumption. This is due to especially high levels of $\mathrm{Cd}, \mathrm{Ni}$, and $\mathrm{Pb}$ in both fish samples. These metals are associated with various diseases for example, $\mathrm{Cd}$ is found to be teratogenic, carcinogenic and possibly, metagenic. Also, $\mathrm{Pb}$ is a poisonous metal which can damage nervous connections (especially in children) and cause blood and brain disorder. Excessive intake of lead can also cause rephropathy. Exposure to Ni causes skin irritation and ulceration.

\section{Recommendation}

Based on the analysis carried out, the following recommendations are made;

1. The general public should be informed and enlightened on the health hazards involved in the consumption of fishes taken from the river.

2. The ministry of health and environment should be notified so that proper actions will be taken immediately

3. More researches should be carried out with more fish species from the river to ascertain these findings.

\section{References}

[1]. Abida, B., HariKrishna S. and Irfanulla K. (2009), Analysis of heavy metals in water and Sediments samples of Madivala Lakes of Bangalore, Karnataka International Journal of ChemTech Research, 1(2): 245-249.

[2]. Adewumi, D. F., Daniyan I. A., Adeodu A. O., (2014). Determination of heavy metals in water, fish and soil samples from Antau River in Keffi, Nasarawa State, Nigeria. J. Chem Soc. Nigeria Vol. 18 pp 57-60.

[3]. Eneji, I.S., Rufus, S., Annune, P.A. (2011). Bioaccumulation of heavy metals in fish (Tilapia Zilli and Claria gariepinus) organs from River Benue. Pak. J. Anal. Environ. Chem. 12(1) 25-31.

[4]. Enkeleda, Luljeta D, Jetmira A, Muhamet Z, Imer H, Dariana B, Fatgzim L.C., Heavy metals in fish for public consumption an consumer protection, Natura Montenegrina, Podogorica. 9(3): 843-851. Accessed 7 July 2013 Available: http://www.pmcg.come/nm9/Ozun,\%20et\%20a\%20ISEM4.pdf

[5]. Indrajit Sen, Ajayi Shandil and V. S. Shriastava, (2011). Study of Determination of Heavy metals in fish species of the River Yamuna (Delhi) by inductively coupled plasma-optical emission spectroscopy (ICP-OES). Advances in Applied Science research, $161-166$

[6]. Jarup L., (2003). Hazards of heavy metal consumption , Pr. Med, Bull. 68:167-182.

[7]. Kaplan, O., N.C. Yildrim, N. Yildrim and M. Cimen, (2011). Toxic elements in animal products and environmental health. Asian J. Anim.Vet. Adv., 6: 228-232.

[8]. Kelle, H. I., Ngbede E. O., Oguezi V. U. and Ibekwe F. C. (2015). Determination of heavy metals in fish (Clarias gariapinus) Orgas from Asaba Major Markets, Delta State, Nigeria. American Chemical Science Journal. 5(2): 135-147.

[9]. Khalifa K.M., Hamil A.M., Al-Houni A.Q.A., Ackacha M.A., (2010). Determination of heavy metals in fish species of the Mediterranean Sea (Libyan coastline) using Atomic Absorption Spectrometry, International Journal of Pharm Tech Research, 2 (2) 1350-1354.

[10]. Lenntech Water Treatment and Air Purification (2004) Water Treatment, Published by Lenntech, Rotterdamseweg Netherland.

[11]. Odumuyiwa O.F., (2009). Assessment of heavy metals in two common fish species (Solea solea and Pseudolithus spp) from Lagos Lagoons in Lagos. A project work submitted to the Department of Environmental Management and Toxicology in the college of Environmental Resource Management, University of Lagos.

[12]. Olade, M.A., (1987) Heavy Metal Pollution and the Need for Monitoring: Illustrated for Developing Countries in West Africa in T.C. Hutchinson and K.M. Meema (eds) Lead, Mercury, Cadmium and Arsenic in the Environment. SCOPE: John Wiley \& Son Ltd.

[13]. Olowu, R. A, Ayejuyo, O. O., Adewuyi, G. O., Babatunde, A. O., Adejoro, I. A, Denloye, A. A. B and Ogundajo A.L (2010). Heavy metals in fish tissue, water, sediment from Epe and Badagry lagoons Nigeria E-Journal of Chemistry 7(1), $215-221$.

[14]. Olowu, R. A., Onwordi, C. T., Denloye, A. A., Osundiya M. O. Adebayo N. O. Owolabi M. S. Tavide O. O. Moronkola B. A Omoyeni O. A and Ajuwon O. R., (2012). Heavy metals in Oreochromis niloticus, Ictalurus punctanus and Bottom sediments from Lagos Lagoon Proximal to Egbin Power Plant, Ijede, Ikorodu, Lagos Nigeria Reseach Journal of Environmental and Earth Sciences 4(3). 237-243.

[15]. Ozmen, H. Kiilah F, Ukurovah, A., and Dogru, M., (2004). Concentrations of heavy metal and radioactivity in surface water and sediment of Hazar lake (Elzlg Turkey) Chemosphere, 55: 401-408.

[16]. Rashed, M.N., (2001). Egypt monitoring of environmental heavy metals in fish from Nasser Lake. Environ. Int., $27: 27-33$.

[17]. WHO, (2003). List of maximum levels of heavy metals recommended for fish by the joint FOA/WHO Codex Alimentarius Commission. $2^{\text {nd }}$ Edn., Rome, Italy, pp: 1-8. 